\title{
Distal Renal Tubular Acidosis in Adolescence with Severe Growth Retardation and Nephrocalcinosis
}

\author{
Sigdel MR, ${ }^{1}$ Kafle MP, ${ }^{1}$ Raut KB' \\ 'Department of Internal Medicine, TU Teaching Hospital, Kathmandu, Nepal.
}

\begin{abstract}
Chronic acidosis is an important, often overlooked cause of growth retardation. Here we present the case of a girl with distal renal tubular acidosis who had visited multiple hospitals before the diagnosis was made. She presented to us in adolescence with non anion gap metabolic acidosis, hypokalemia, severe growth retardation and nephrocalcinosis. In 18 months follow up with alkali therapy, she had good weight gain and growth velocity.
\end{abstract}

Keywords: growth retardation; hypokalemia; nephrocalcinosis; renal tubular acidosis.

\section{INTRODUCTION}

Kidneys maintain acid base homeostasis by reabsorption of filtered bicarbonate and net excretion of $1 \mathrm{mmol} / \mathrm{kg} /$ day of $\mathrm{H}^{+}$. Any defect in either of these two results in renal tubular acidosis (RTA), proximal renal tubular acidosis (type 2) and distal renal tubular acidosis (dRTA, type 1) respectively. ${ }^{1,2}$ dRTA was first described in 1946 by Albright. $^{3}$ Inherited dRTA can be either autosomal-recessive or autosomal-dominant, the former often presents in infancy, whereas the latter may not present until adolescence or young adulthood. ${ }^{4}$

RTA in infants usually presents with failure to thrive, polyuria, irritability, and recurrent vomiting. Older child may present with nocturia, fatigue, constipation, myalgia, and muscle weakness due to hypokalemia. ${ }^{5} \mathrm{Gait}$ disturbance, osteoporosis, rickets, growth retardation and nephrocalcinosis are other presentations of dRTA. Sometimes patients may present due to the associated findings like mental retardation or deafness. ${ }^{5}$

The key to management of RTA lies in early diagnosis. Bicarbonate therapy, mean dose of $3.5 \mathrm{mEq} / \mathrm{kg}$ per day, to a target $\mathrm{HCO}^{-}$level of $\geq 22$ makes the cornerstone of therapy for $\mathrm{dRTA}^{6}$. However, diagnosis of RTA is often missed in a child. ${ }^{5}$ Here we present a girl with dRTA whose diagnosis could not be made till adolescence despite having severe growth retardation and nephrocalcinosis.

\section{CASE REPORT}

A 14 years girl, student of $7^{\text {th }}$ grade, from mid western Nepal was brought to nephrology outpatient clinic of Tribhuvan University Teaching Hospital Kathmandu in February 2011 with history of failure to gain age appropriate height and weight since early childhood. She was second amongst three siblings, borne out of non consanguineous marriage as full term normal vaginal delivery with birth weight of $3 \mathrm{KG}$. Her early developmental milestones were normal till the age of two years. She had completed childhood vaccination, had good sun exposure in her childhood. After 2 years

Correspondence: Dr. Mahesh Raj Sigdel, Department of Internal Medicine, TU Teaching Hospital, Kathmandu, Nepal. Email: maheshsigdel@hotmail.com 
of age, she lost appetite and lagged behind in growth compared to her peers; it consisted of lesser height and weight. However, her scholastic performances remained unaffected; she had no visual complaints, headache, abnormal behavior or neurological problems. She did not have major febrile illnesses, shortness of breath, cyanotic spells, persistent loose motion, vomiting, physical deformities or gait disturbances.

After the age of two and half years she complained of vague calf pain that persisted till presentation. She had constipation for a few months at the age of 8-9 years. She had nocturia. She had not attained menarche; there was no appearance of secondary sexual characters. Her siblings were normal. Parents had average height and constitution. Mother had attained puberty and menarche at usual age. There was no family history of similar problem. Earlier, she was taken to local hospital multiple times where a diagnosis of constitutional delay was made. She was referred from pediatric outpatient department as screening ultrasound abdomen revealed nephrocalcinosis.

On examination, her height was $120 \mathrm{~cm}$ and weight $16 \mathrm{KG}$ with body mass index of $11.1 \mathrm{~kg} / \mathrm{m}^{2}$. Her pulse was $80 / \mathrm{min}, \mathrm{BP} 90 / 60 \mathrm{~mm}$ of $\mathrm{Hg}$. There was no pallor, icterus, cyanosis, clubbing, edema or lymphadenopathy. She had no bony deformities; eyes, hearing, chest, cardiovascular, abdominal and neurological examinations were normal. Thelarche and other secondary sexual characters were absent.

On investigation, her complete blood count was normal. Blood sugar was $6.1 \mathrm{mmol} / \mathrm{L}$, serum creatinine 75 micro $\mathrm{mol} / \mathrm{L}$, uric acid $121 \mathrm{micro} \mathrm{mol} / \mathrm{L}, \mathrm{Na} 135 \mathrm{mEq} / \mathrm{L}$ and $\mathrm{K} 3.2 \mathrm{mEq} / \mathrm{L}$. Calcium was $2.0 \mathrm{mmol} / \mathrm{L}$, Phosphorus $4.2 \mathrm{mg} / \mathrm{dl}$, albumin $47 \mathrm{gm} / \mathrm{L}$ and ALP $1545 \mathrm{u} / \mathrm{L}$. Urine routine and microscopic was normal; early morning urine $\mathrm{pH}$ was 6.5. Twenty four hour urinary protein, uric acid and calcium were $0.47 \mathrm{gm} /$ day, $1535 \mathrm{micromol} /$ day and $2.9 \mathrm{mmol} /$ day respectively. Thyroid function was normal. X-ray KUB abdomen was suggestive of renal medullary calcification. Arterial blood gas (ABG) revealed $\mathrm{pH} 7.31, \mathrm{pCO}_{2} 28 \mathrm{mmHg}, \mathrm{HCO}_{3}-13.7 \mathrm{mmol} / \mathrm{L}$, $\mathrm{Cl}^{-} 115 \mathrm{mmol} / \mathrm{L}$ and anion gap of 6.3 . With a diagnosis of dRTA, she was started on sodium bicarbonate 2 $\mathrm{mEq} / \mathrm{kg} /$ day in three split doses.

At the first follow up at two months, she gained 4 $\mathrm{cm}$ height and $4 \mathrm{KG}$ weight. $\mathrm{K}^{+}$now was $4.2 \mathrm{mEq} / \mathrm{L}$ and ALP(alkaline phosphatase) was $660 \mathrm{mmol} / \mathrm{L}$. ABG(Arterial Blood Gas) revealed $\mathrm{pH}$ 7.42, $\mathrm{pCO}_{2} 27.7$, $\mathrm{HCO}_{3}^{-}$18.4. The dose of sodium bicarbonate was uptitrated. Second follow up was one year later when height was $137 \mathrm{~cm}$ and weight $26 \mathrm{~kg}$. ABG revealed $\mathrm{pH}$ 7.36, $\mathrm{pCO}_{2} 26.8 \mathrm{mmHg}, \mathrm{HCO}_{3}-15.4 \mathrm{mmol} / \mathrm{L}$. Her $\mathrm{Ca}$ was $2.0 \mathrm{mmol} / \mathrm{L}$, albumin $46 \mathrm{gm} / \mathrm{L}$, phosphorus $5.1 \mathrm{mg} /$ dl and ALP 660 u/L. Serum creatinine and urine routine were normal and nephrocalcinosis on Ultrasonography was static. The need for strict compliance was reinforced. Dose of soda-bicarbonate was again uptitrated to $3 \mathrm{mEq} / \mathrm{kg} / \mathrm{day}$, higher dose given at night.

At last follow up in August 2012, her height was 139 $\mathrm{cm}$ and weight was $28 \mathrm{KG}$. ABG showed $\mathrm{pH} 7.52$, $\mathrm{pCO}_{2} 26.1, \mathrm{HCO}^{-20.7}, \mathrm{Cl}^{-} 105$ and anion gap 11.1. With 18 months treatment, she gained a total of 12 KGs weight and $19 \mathrm{~cm}$ height. She attained menarche 3 months prior to her last follow up. She was continued on alkali therapy.

\section{DISCUSSION}

Failure to gain age appropriate height and weight is a common reason for pediatrician consultation. The causes range from constitutional delay to chronic illnesses, chronic acidosis, major organ dysfunction, endocrinopathies, skeletal dysplasias and chromosomal disorders. ${ }^{5,7}$ Our child's diagnosis was missed by multiple health professionals. Probable reasons are: $\mathrm{HCO}^{-}$is not part of routine biochemistry panel in Nepal, many hospitals do not have ABG machine and there is general unfamiliarity amongst doctors about RTA.

dRTA is characterized by non anion gap metabolic acidosis (serum bicarbonate as low as $10 \mathrm{Meq} / \mathrm{L}$ ), hypokalemia, persistently high urine $\mathrm{pH}>5.5$ and positive urine anion gap (UAG) ${ }^{1,2}$. Bone buffers $\mathrm{H}^{+}$during chronic metabolic acidosis resulting in osteoporosis, bony deformities and hypercalciuria. ${ }^{8}$ The combination of hypercalciuria, hypocitraturia, hyperphosphaturia and a high urinary $\mathrm{pH}$ predispose dRTA patients to nephrocalcinosis. ${ }^{7}$ The mechanism of growth retardation in acidosis is multifactorial: reduced food intake, increased protein catabolism and inhibitory effect of acidosis on growth hormone secretion/function and growth plate. ${ }^{9}$ Our diagnosis of dRTA was made based on growth retardation in a child with non gap metabolic acidosis with bicarbonate of $13.7 \mathrm{mmol} / \mathrm{L}$, hypokalemia, urine $\mathrm{pH}$ of 6.5 , nephrocalcinosis and absence of diarrhoea. Absence of diarrhoea preempted the need for UAG. ${ }^{2}$ This diagnosis was confirmed as she responded to low dose of bicarbonate therapy with significant linear growth, weight gain and correction of hypokalemia. ${ }^{6}$

Patients with dRTA have defects in kidney anion exchanger-1 (KAE1), $\mathrm{H}^{+}$-ATPase or carbonic anhydrase (CA) $11 .{ }^{10}$ Because of late presentation, absence of hearing impairment and absence of any neurological findings, the molecular defect in our patient is likely to be in the electroneutral anion exchanger (AE1, $\mathrm{Cl}^{-} / \mathrm{HCO}^{-}$exchanger) encoded by SLC4A1 gene on chromosome $17 .{ }^{10}$ However, there was no family history of dRTA. Genetic analysis was not done because it is 
not available in our set up.

For the first 6 months, patients of RTA should be monitored monthly with serum bicarbonate, urinary calcium, weight and linear growth. ${ }^{2}$ Nephrocalcinosis should be monitored annually. ${ }^{1,6}$ Because our patient was a student from remote place, only four visits in one and half years could be achieved. However the overall gain in height of $19 \mathrm{~cm}$ over 18 months $(12.67 \mathrm{~cm} /$ year) was significantly higher than the average pubertal growth of $8.3 \mathrm{~cm} /$ year in a girl. ${ }^{5,6}$ However, she may not attain the final expected height because of late introduction of therapy. ${ }^{6}$

Renal tubular acidosis can present with weakness, nocturia, growth retardation and nephrocalcinosis in a child. Timely diagnosis and management with alkali therapy can ensure normal growth and development.

\section{REFERENCES}

1. Palmer BF, Alpern J, Normal acid base balance, metabolic acidosis. In: Floege J, Johnson RJ, Feehaly J, editors. Comprehensive clinical nephrology. St Louis Missouri: Elsevier Saunders. 2010. p. 149-66.

2. Thomas D, DuBose Jr, Disorders of acid-base balance. In: Taal MW, Chertow GM, Marsden PA, Skorecki K, Yu ASL, Brenner BM, editors. Brenner \& Rector's The Kidney. Philadelphia: Elsevier Saunders. 2012. p. 595-639.

3. Albright F, Burnett $\mathrm{CH}$, Parson W. Osteomalacia and late rickets; the various etiologies met in the United States with emphasis on that resulting from a specific form of renal acidosis, the therapeutic indications for each etiological sub-group, and the relationship between osteomalacia and Milkman's syndrome. Medicine. 1946 Dec;25(4):399-479.

4. Karet FE. Inherited distal renal tubular acidosis. J Am Soc Nephrol. 2002 Aug;13(8):2178-84.
5. Chan JCM, Santos F. Renal tubular acidosis in childhood. World J Pediatr. 2007;3(2):92-7.

6. Sabatini S, Kurtzman N. Bicarbonate therapy in severe metabolic acidosis. J Am Soc Nephrol. 2009;20:692-5. Epub 2008 Mar 5.

7. Nicoletta JA, Schwartz GJ. Distal renal tubular acidosis. Curr Opin Pediatr. 2004 Apr;16(2):194-8.

8. Krieger NS, Frick KK, Bushinsky DA. Mechanism of acid-induced bone resorption. Curr Opin Nephrol Hypertens. 2004;13:423-36.

9. Kuemmerle N, Krieg RJ Jr, Latta K, Challa A, Hanna JD, Chan JC. Growth hormone and insulin-like growth factor in non-uremic acidosis and uremic acidosis. Kidney Int Suppl. 1997 Mar;58:S102-5.

10. Laing CM, Toye AM, Capasso G, Unwin RJ. Renal tubular acidosis: developments in our understanding of the molecular basis. Int J Biochem Cell Biol. 2005;37:1151-61. 